\title{
Influence of agronomic factors on the relationship between forage production and seed yield in perennial forage grasses and legumes in a Mediterranean environment
}

\author{
Pasquale Martiniello \\ Istituto Sperimentale per le Colture Foraggere, SOP di Foggia, Via Napoli, 5271 100, Foggia, Italy
}

(Received 10 February 1998; accepted 24 August 1998)

\begin{abstract}
Accessions (varieties and ecotype) of perennial legumes, lucerne (cv Equipe and ecotype Romagnola), sulla (cvs Bellante and Sant'Omero) and sainfoin (cvs Zeus and Vala), and grasses, tall fescue (cvs Tanit and Sibilla), cocksfoot (cvs Dora and Cesarina) and perennial ryegrass (cvs Vejo and Pamir) were investigated for performance in a typical Mediterranean environment (Foggia, southern Italy). The accessions were evaluated for yield potential in seed and forage dry matter and the relationship between yield component traits under rainfed and two irrigation treatments and forage harvest management was investigated. The traits investigated were forage production (dry matter, stem density and plant height) and seed yield (seed yield, 1000 seed weight, stem density and seeds per stem). The results showed a significant difference among traits across the treatments. Early flowering of the accessions is the characteristic able to increase dry matter and seed yield in grass and legume species. Dry matter of the first harvest of the year was weakly influenced by irrigation treatments. The species and accessions showed different adaptability to exploit the forage and seed yield potential in the weather conditions under study. Irrigation treatment with a higher level of water application increased positively, in grasses and legumes, the correlation dry matter with stems per $\mathrm{m}^{2}$ of the sward and negatively the correlation seed yield with seed weight in grasses and positively with stem density in legumes. Irrigation was the main agronomic factor which resulted in an ability to increase the period of crop utilisation, the seed yield, and to stabilise seed production in Mediterranean areas. (@ Inra/Elsevier, Paris.)
\end{abstract}

forage crops / perennial grasses and legumes / agronomic factors / seed and biomass yield

Résumé - Influence de facteurs agronomiques sur la relation entre la production de fourrage et le rendement en grain chez les graminées pérennes et les légumineuses fourragères dans un environnement méditerranéen. Différentes populations (écotypes et variétés) appartenant aux espèces légumineuses pérennes suivantes : luzerne (cv

Communicated by Mike Hayward (Aberystwyth, UK)

* Correspondence and reprints

Tel-Fax +39.881.741632; E-mail: iscf.fg@isnet.it 
Équipe et écotype Romagnola), sainfoin d'Italie (cv Bellante et Sant' Omero) et sainfoin (cv Zeus et Vala) et aux graminées suivantes : fétuque élevée (cv Tanit et Sibilla), dactyle (cv Dora et Cesarina) et ray-grass anglais (cv Vejo et Pamir) ont été étudiées pour leur performance en milieu méditerranéen (Foggia, Italie du Sud). L'effet de différents régimes hydriques et des rythmes d'exploitation sur le potentiel productif en grains et en fourrage et sur les composantes du rendement a été étudié. Les caractères considerés pour la production de fourrage ont été la matière sèche totale, la densité des tiges et la hauteur de la plante et, pour la production de semences, le rendement en grain, le poids de 1000 grains, la densité des tiges et le poids des grains par tige. Les résultats ont montré des effets significatifs des traitements sur les caractères considérés. La précocité de floraison, en particulier, est corrélée au rendement en fourrage et en grain aussi bien chez les légumineuses que chez les graminées. L'effet des régimes hydriques sur la première coupe de l'année a été faible. Les espèces et populations étudiées ont montré un degré différent d'adaptation à exploiter leur potentiel productif en milieu méditerranéen. Au niveau le plus élevé d'irrigation, la corrélation entre production de matière sèche et densité des tiges est augmentée pour les légumineuses et pour les graminées. La corrélation entre production totale et poids unitaire de la graine est négative quand augmente la quantité d'eau d'irrigation pour les graminées. Dans le cas des légumineuses, un effet positif du niveau d'irrigation sur la production de grains et la densité des tiges est observé. L'irrigation s'est avéré le facteur agronomique le plus important pour étendre la période d'utilisation de la culture et pour augmenter et rendre plus stable la production de semences en milieu méditerranéen. (๑ Inra/Elsevier, Paris.)

cultures fourragères / légumineuses et graminées pérennes / facteurs agronomiques / rendement en grains et en biomasse

\section{INTRODUCTION}

Seed production of crops of perennial legumes and forage grasses in Mediterranean environments is related to the amount of evaporation, rainfall and temperature during the period of plant growth $[2$, $10,13,18]$. Cultivation of perennial forage crops in these environments requires appropriate agronomic techniques to counteract the impact of variable weather conditions on seed production. Studies on agronomic factors which influence the relationship between traits of biomass and seed production components are useful for improving management techniques and increasing, in particular, seed production $[5,7-9,13,16]$.

Knowledge of the effect of agronomic factors on relationships between yield components of perennial forage crops in Mediterranean environments requires a determination of the influence of the agronomic factors on the exploitation of the herbage and seed yield potential of the accessions $[5,7,13,14,16]$. Thus, studies to examine and quantify the effect of agronomic factors on perennial grasses and legumes are important for developing appropriate management techniques to fully exploit the seed and biomass potential of cultivated varieties.
The objectives of the study were to evaluate: i) the influence of irrigation and forage harvest management on dry matter and seed production; and ii) relationships between dry matter and seed yield with yield component traits and the relationship between yearly total dry matter production with seed yield of perennial legume and grass forage crop accessions in Mediterranean regions.

\section{MATERIALS AND METHODS}

Trials were carried out during the years 1993-1996 at the experimental farm of the Forage Crops Institute of Foggia (southern Italy, typical Mediterranean environment) on mixed black clay-loam, mesic Typic Cromoxererts. Certified seeds of two cultivars of grasses (cocksfoot (Dactylis glomerata L.), Dora and Cesarina; perennial ryegrass (Lolium perenne L.), Pamir and Vejo; tall fescue (Festuca arundinacea Screb.), Sibilla and Tanit) and as many as accessions of legumes (sainfoin (Onobrychis viciifolia Scop.), Vala and Zeus; sulla (Hedvarum coronarium L.), Bellante and Sant'Omero and one variety of lucerne (Medicago sativa L.) cv Equipe and one ecotype Romagnola) were used in the experiments. These accessions represent the genotypes of perennial forage crops generally widespread in Mediterranean agriculture. 
The experimental scheme was a factorial design laid out in a split-plot arrangement. The main plot was the irrigation treatment and harvest management in three sub-plots (herbage, seed yield of regrowth after the first forage harvest and seed production without harvest). In the sub-plot, the accessions of each species of grass and legume were replicated four times. The experimental unit was the sub-sub-plot of $7.5 \mathrm{~m}^{2}$, consisting of eight rows equally spaced, $5 \mathrm{~m}$ in length and $0.17 \mathrm{~m}$ apart. Seedbed preparation consisted of ploughing to a depth of $40 \mathrm{~cm}$ during the third week of August. The crop prior to the legumes was durum wheat (Triticum durum Desf.) and berseem (Trifolium alexandrinum L.) before the grasses. Chemical fertiliser $\left(32 \mathrm{~kg} \mathrm{ha}^{-1}\right.$ of nitrogen as ammonia and $70 \mathrm{~kg} \mathrm{ha}^{-1}$ of $\mathrm{P}_{2} \mathrm{O}_{5}$ as biphosphate) was applied to the ploughed soil 2 weeks before seeding, which was accomplished by a small-plot seeder in the second week of October 1992. For the grass plots, after each harvest, nitrogen fertiliser was applied at the rate of $40 \mathrm{~kg} \mathrm{ha}^{-1}$ as urea after the first cut and $30 \mathrm{~kg} \mathrm{ha}^{-1}$ after subsequent harvests. Furthermore, in each year after the planting year, at the end of February, weeds were removed by hoeing and winter growth of the crops by a clearing cut and then both forage and seed evaluation plots were fertilised with nitrogen and phosphorus at the respective rates of 70 and $90 \mathrm{~kg} \mathrm{ha}^{-1}$ in grasses and $90 \mathrm{~kg}$ $\mathrm{ha}^{-1}$ of phosphorus in legumes.

Irrigation treatments were: non-irrigated (rainfed), irrigation until June (A) and irrigation for the whole year (B). In both irrigation treatments, water was applied to the crops when evaporation (ET) reached $80 \mathrm{~mm}$ according to Doorenbos and Pruitt [4]. The number of waterings, the total amount of water applied and the evaporation that occurred during the years of evaluation are reported in table 1 . The trials were irrigated using a horizontal bar $16 \mathrm{~m}$ long, $1.23 \mathrm{~m}$ above the soil surface and with a nozzle pressure of $0.19 \mathrm{MPa}$.

The first harvest was taken when $15-20 \%$ of stems had flowered; and the flowering date of entry was recorded (FD, expressed as days from first January). Subsequent forage harvests were taken when stems of plot reached the same phenological stage of the first cut (29 and 31 days, on average over the year of evaluation, in grasses and legumes, respectively). Seed harvests of plots with forage and without forage harvests, were carried out when seed moisture content (determined by testing a small seed sample by moisture meter) was approximately $15 \%$. Forage and seed harvest were both carried out mechanically by a small-plot harvester.

On each experimental unit used for forage evaluation, the following traits were measured: plant height $(\mathrm{PH}$, $\mathrm{cm}$; mean of six values taken from ground level to main
Table I. Number of waterings and total water applied in the irrigation treatments $\mathrm{A}$ and $\mathrm{B}$ and monthly evaporation occurring in the 4-years of experiments $(I=1993$, II $=1994$, III $=1995$ and IV $=1996$ ).

\begin{tabular}{|c|c|c|c|c|}
\hline \multirow{2}{*}{$\begin{array}{l}\text { Description } \\
\text { of treatment }\end{array}$} & \multicolumn{4}{|c|}{ Year of evaluation } \\
\hline & I & II & III & IV \\
\hline Irrigation & \multicolumn{4}{|c|}{ Treatment A } \\
\hline $\begin{array}{l}\text { Number of } \\
\text { applications }\end{array}$ & 6 & 6 & 5 & - \\
\hline $\begin{array}{l}\text { Total water } \\
\text { applied }\left(\mathrm{mm} \mathrm{ha}^{-1}\right)\end{array}$ & 300 & 300 & 250 & - \\
\hline Irrigation & \multicolumn{4}{|c|}{ Treatment B } \\
\hline $\begin{array}{l}\text { Number of } \\
\text { applications }\end{array}$ & 13 & 12 & 11 & 10 \\
\hline $\begin{array}{l}\text { Total water } \\
\text { applied }\left(\mathrm{mm} \mathrm{ha}^{-1}\right)\end{array}$ & 650 & 600 & 550 & 500 \\
\hline Month & \multicolumn{4}{|c|}{ Monthly evaporation ( $\mathrm{mm}$ ) } \\
\hline April & 147 & 134 & 118 & 112 \\
\hline May & 189 & 203 & 195 & 173 \\
\hline June & 261 & 240 & 236 & 255 \\
\hline July & 315 & 300 & 287 & 345 \\
\hline August & 329 & 321 & 206 & 261 \\
\hline September & 172 & 199 & 161 & 142 \\
\hline October & 121 & 117 & 132 & 96 \\
\hline Yearly amount & 1806 & 1797 & 1642 & 1632 \\
\hline
\end{tabular}

apex); stem density (SD, stems $\mathrm{m}^{-2}$; assessed on two samples taken from two $0.5 \mathrm{~m}$ of row) and dry matter yield $\left(\mathrm{DM}, \mathrm{t} \mathrm{ha}^{-1}\right)$. The dry matter content of the forage at harvest was assessed on fresh herbage from each experimental unit, and adjusted for moisture content determined from a sample of approximately $500 \mathrm{~g}$ of fresh weight. On the plots used for seed production, the traits evaluated were: seed yield (SY, $\mathrm{kg} \mathrm{ha}^{-1}$; at $13 \%$ of standard moisture content), stem density (SD, stems $\mathrm{m}^{-2}$; determined as for the forage treatment), and components of seed yield (inflorescences per stem, seeds per inflorescence, seeds per stem and seed weight). Seed yield components were determined from ten stems taken at random from those used for assessing stem density. The characters scored were: seeds stem ${ }^{-1}$ (SS, no.), 1000 seed weight (SW, g) and harvest index (seed weight from stems as percentage of the biomass for stems cut at ground level). 


\subsection{Statistical analysis}

Analysis of variance was performed on data of dry matter and seed yield and their yield components of the irrigation treatments and forage harvest management. In the models, year of evaluation, irrigation treatments, harvest management, species, accessions and replications were taken as fixed factors [17]. The arcsine $\sqrt{\%}$ transformation was made on percentage data before analysis. Data from dry matter harvests of each species and irrigation treatments were processed with the analysis of variance. In each species, to assess the significance of the main effects of irrigation treatments, differences between means of the dry matter and seed yield and their yield component traits were compared by Duncan's multiple range test; and the effect of year of evaluation within irrigation treatment by the least significant difference procedure. Analysis of variance for determining significance between species was based on unequal sub-class number of means for replication across the period of evaluation according to the procedure described by Steel and Torrie [17].

In each species, relationships between traits under rainfed and irrigation treatments were estimated by simple correlation analysis carried out on data of replications of the accessions. The correlations assessed were: 1) dry matter production between its yield components and dry matter with flowering data calculated using the data of first harvest averaged over the rainfed and irrigation treatments of 1993 and 1994; 2) seed yield with the yield component stem density and seed weight, and seed yield with harvest index were computed using the data of seed harvest in the years of evaluation; and 3) seed yield with total dry matter produced assessed utilising the data of the years of evaluation.

\section{RESULTS}

Irrigation treatments increased the persistence of crop utilisation for both dry matter and seed production in all grass and legume species (figure 1 and table $I I)$. Dry matter of the first harvest in all years of evaluation, species and irrigation treatments showed the highest values and did not differ between rainfed and irrigated treatments, except in 1993 in lucerne and sainfoin and in all species of grasses in 1995 (figure I). In rainfed and in irrigation treatments, dry matter yield, as a consequence of lower plant establishment, was lower in the first than in the second year of evaluation in cocksfoot, tall fescue, lucerne and sainfoin. The highest dry matter was produced, in all species and in both irrigation treatments, in the second year of evaluation (figure I). Moreover, after the second year of evaluation the accessions, of both legumes and grasses under rainfed conditions, died. The increase in dry matter in the first harvest of the second year (mean of irrigation treatments over the years 1993 and 1994) was about $41 \%$ higher, in both legumes and grasses than the production of the first year of evaluation. The average increase in dry matter in the years 1993 and 1994 of irrigation treatments, in the second harvest was statistically significant and increased the total production of dry matter in treatments A and B by 12 and $29 \%$ in grasses and 28 and $35 \%$ in legumes (data not shown), respectively.

Because the crops for seed production remain exposed to weather conditions for a longer period than for forage production, seed yield under rainfed conditions was significantly reduced (mean over the years of evaluation) in both grasses and legumes by 30 and $52 \%$ in irrigation treatment $A$ and 49 and $72 \%$ in treatment $B$, respectively (means not reported in table II). The agronomic conditions promoted by irrigation treatment $B$ enhanced by 1 year the period of agronomic utilisation of the sward for seed production and significantly increased seed yield (computed in the years where treatments $A$ and B had seed production) by $39 \%$ in grasses and $49 \%$ in legumes compared to irrigation treatment A. The seed yield decrease, observed in the last year of evaluation in treatment $\mathrm{B}$, was a consequence of a reduction in stem density (table II). Other seed characters were also influenced by increasing water availability. Among species, the effect of irrigation treatment A, across the year of evaluation, significantly affected seed weight in cocksfoot, tall fescue and sulla; and seed weight in all species of grass and legume under treatment $\mathrm{B}$. The seed characters influenced by increased irrigation treatment $B$ (in the years of evaluation where comparison of both treatments $\mathrm{A}$ and $\mathrm{B}$ are available) were the traits: stem density in tall fescue and sulla, seed weight in lucerne and seeds per stem in sainfoin and sulla 
Table II. Mean of seed yield and its seed yield component traits under irrigation treatments $($ Rainf $=$ rainfed, Tre $A=$ treatment $\mathrm{A}$ and Tre $\mathrm{B}=$ treatment $\mathrm{B}$ ) in the years of evaluation.

\begin{tabular}{|c|c|c|c|c|c|c|c|c|c|c|c|c|c|}
\hline \multirow{2}{*}{ Species } & \multirow{2}{*}{$\begin{array}{c}\text { Year of } \\
\text { evaluation }\end{array}$} & \multicolumn{3}{|c|}{ Seed yield } & \multicolumn{3}{|c|}{ Seeds stem } & \multicolumn{3}{|c|}{ Seed weight } & \multicolumn{3}{|c|}{ Stem density } \\
\hline & & Rainf & Tre A & Tre B & Rainf & Tre A & Tre B & Rainf & Tre A & Tre B & Rainf & Tre A & Tre B \\
\hline \multirow[t]{4}{*}{ Cocksfoot } & I & $181 \mathrm{a}$ & $172 \mathrm{a}$ & $362 b$ & $40 \mathrm{a}$ & $52 b$ & $82 \mathrm{c}$ & $0.67 \mathrm{a}$ & $0.84 b$ & $0.91 \mathrm{c}$ & $308 \mathrm{a}$ & $372 b$ & $394 b$ \\
\hline & II & - & $175 \mathrm{a}$ & $483 b$ & - & $62 a$ & $87 \mathrm{~b}$ & - & $0.66 \mathrm{a}$ & $0.94 b$ & - & $359 a$ & $326 b$ \\
\hline & III & - & $154 a$ & $324 b$ & - & $69 \mathrm{a}$ & $81 \mathrm{~b}$ & - & $0.68 \mathrm{a}$ & $1.34 \mathrm{a}$ & - & $354 a$ & $337 \mathrm{a}$ \\
\hline & IV & - & - & 262 & - & - & 61 & - & - & 1.54 & - & - & 161 \\
\hline LSD 0.05 & & & 19 & 72 & & 8 & 7 & & 0.12 & 0.12 & & 21 & 65 \\
\hline Perennial & I & $171 \mathrm{a}$ & $173 a$ & $285 b$ & $52 a$ & $62 b$ & $57 a$ & $1.37 \mathrm{a}$ & $1.41 \mathrm{a}$ & $2.01 \mathrm{~b}$ & $1376 a$ & $1321 \mathrm{a}$ & $1131 b$ \\
\hline \multirow[t]{2}{*}{ ryegrass } & II & $112 \mathrm{a}$ & $352 b$ & $411 \mathrm{c}$ & $55 \mathrm{a}$ & $53 a$ & $62 a$ & $1.24 \mathrm{a}$ & $1.34 \mathrm{a}$ & $1.40 \mathrm{a}$ & $1275 a$ & $1472 a$ & $1274 a$ \\
\hline & III & - & - & 162 & - & - & 51 & - & - & 1.86 & - & - & 776 \\
\hline LSD 0.05 & & 30 & 77 & 94 & NS & 9 & 8 & 0.11 & NS & 0.10 & 38 & 98 & 89 \\
\hline Tall & I & $158 \mathrm{a}$ & $162 \mathrm{a}$ & 300 & $37 a$ & $43 a$ & 38 & $1.54 \mathrm{a}$ & $1.98 \mathrm{~b}$ & 2. & $374 a$ & $461 b$ & $515 c$ \\
\hline \multirow{3}{*}{ fescue } & II & $133 a$ & $342 \mathrm{a}$ & $366 b$ & $36 \mathrm{a}$ & $55 \mathrm{~b}$ & $42 \mathrm{a}$ & $1.07 \mathrm{a}$ & $1.19 \mathrm{~b}$ & $1.70 \mathrm{c}$ & $381 \mathrm{a}$ & $516 b$ & $589 \mathrm{c}$ \\
\hline & III & - & $155 \mathrm{a}$ & $322 b$ & - & $49 \mathrm{a}$ & $47 \mathrm{a}$ & - & $1.69 \mathrm{a}$ & $2.26 b$ & - & $409 a$ & $590 \mathrm{c}$ \\
\hline & IV & - & - & 318 & - & - & 52 & - & - & 2.09 & - & - & 471 \\
\hline LSD 0.05 & & NS & 84 & 52 & NS & 7 & 10 & 0.15 & 0.19 & 0.11 & NS & 35 & 71 \\
\hline \multirow[t]{3}{*}{ Lucerne } & I & $184 a$ & $202 a$ & 332 & $51 \mathrm{a}$ & $76 b$ & 73 & $1.81 \mathrm{a}$ & $1.96 \mathrm{~b}$ & 2.1 & $271 \mathrm{a}$ & $378 b$ & $334 b$ \\
\hline & II & - & $257 \mathrm{a}$ & $633 b$ & - & $65 a$ & $135 b$ & - & $1.41 \mathrm{a}$ & $2.18 \mathrm{~b}$ & - & $340 \mathrm{a}$ & $390 a$ \\
\hline & III & - & - & 532 & - & - & 112 & - & - & 1.95 & - & - & 298 \\
\hline LSD 0.05 & & & NS & 93 & & 9 & 18 & & NS & 0.11 & & 21 & 57 \\
\hline \multirow[t]{3}{*}{ Sainfoin } & I & $261 a$ & $732 b$ & $1554 \mathrm{c}$ & $33 a$ & $74 b$ & $152 \mathrm{c}$ & $24.9 b$ & $16.4 \mathrm{a}$ & $18.3 \mathrm{a}$ & $415 a$ & $541 b$ & $523 b$ \\
\hline & II & - & $783 a$ & $1411 b$ & - & $76 a$ & $144 b$ & - & $16.2 \mathrm{a}$ & $17.3 \mathrm{a}$ & - & $448 \mathrm{a}$ & $539 b$ \\
\hline & III & - & - & 828 & - & - & 183 & - & - & 15.7 & - & - & 471 \\
\hline LSD 0.05 & & & NS & 111 & & NS & 27 & & NS & 0.8 & & 71 & 41 \\
\hline \multirow[t]{3}{*}{ Sulla } & I & $411 a$ & $611 b$ & 102 & 46 & $72 \mathrm{l}$ & 14 & $11.2 \mathrm{a}$ & $9.9 \mathrm{a}$ & & $234 a$ & $286 a$ & $316 \mathrm{~b}$ \\
\hline & II & $292 a$ & $523 b$ & $1184 \mathrm{c}$ & $38 \mathrm{a}$ & $54 b$ & $184 \mathrm{c}$ & $12.4 \mathrm{~b}$ & $10.9 \mathrm{a}$ & $11.2 b$ & $272 a$ & $245 \mathrm{a}$ & $377 b$ \\
\hline & III & - & - & 572 & - & - & 118 & - & - & 8.5 & - & - & 223 \\
\hline LSD 0.05 & & 72 & 70 & 92 & NS & 11 & 20 & NS & 0.9 & 0.8 & 36 & 28 & 28 \\
\hline
\end{tabular}

Mean with same letter across irrigation treatments did not differ at $P<0.05$ probability level at multi-range Duncan test. Mean of trait within irrigation treatment over the years of evaluation tested with least significant difference at $P<0.05$ level of probability. NS $=$ not significant.

(table II). Cultivars of all species, except cocksfoot under rainfed conditions in 1994 , were statistically different in dry matter production and, excluding cocksfoot and sulla in 1993, not significant for seed yield. Moreover, irrigation treatments $\mathrm{A}$ and $\mathrm{B}$ increased, to a different extent, dry matter and seed yield of the grass and legume accessions during the year of evaluations. Among legume species, accessions of lucerne, because they are less sensitive than other species to summer dormancy, are at a greater advantage from irrigation treatment $B$ than the other species (data not shown). 

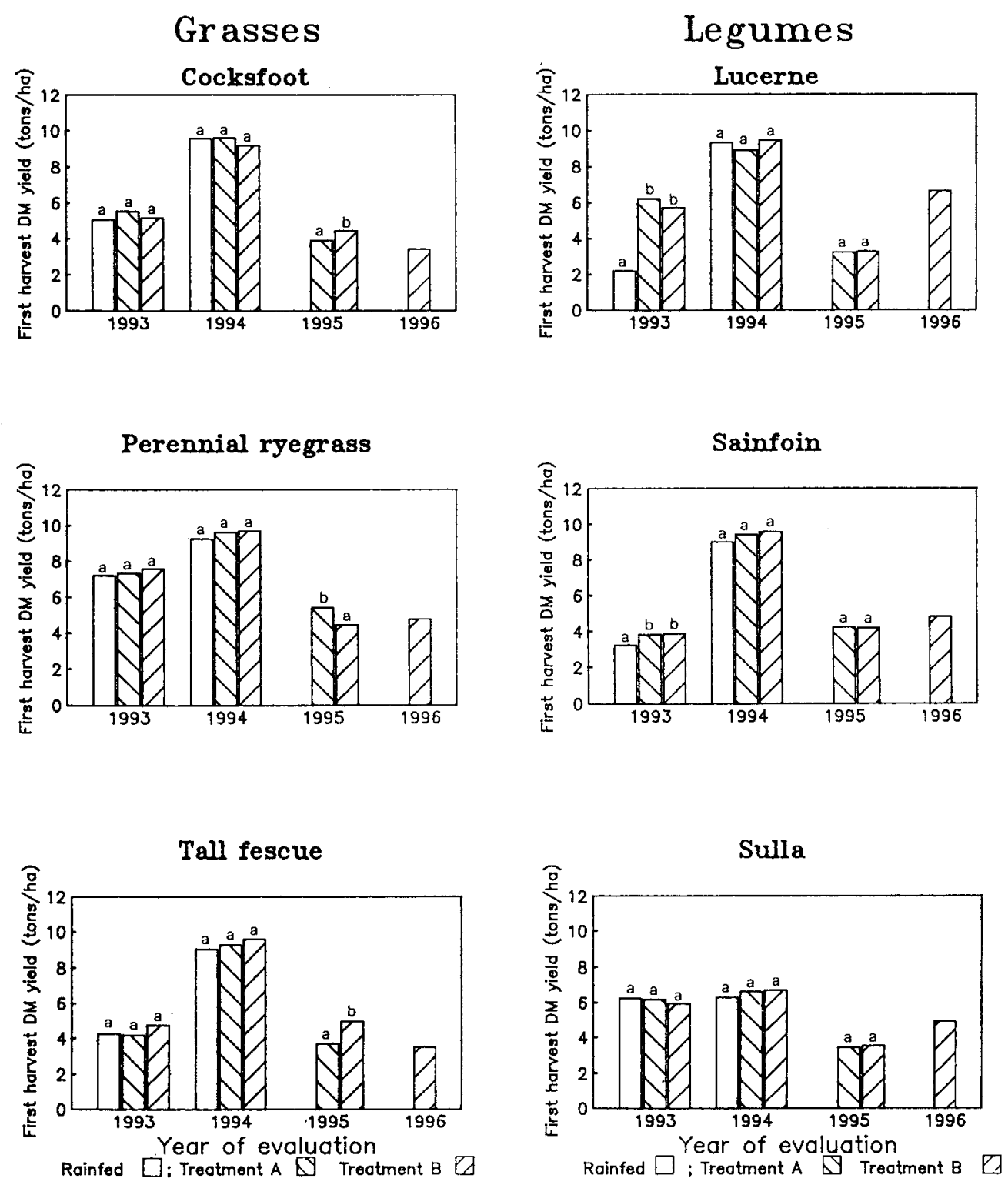

Figure 1. Effect of irrigation treatments in the year of evaluation on dry matter of the first harvest in the year of evaluation in species of grasses and legumes. Within irrigation treatments in the year of evaluation, bars marked with the same letter differed according to Duncan's multi-range test at $P<0.05$.

\subsection{Correlation among traits}

\subsubsection{Dry matter yield and its yield components}

The negative correlations observed in all species between dry matter and days to flowering except sulla (species with lower flowering data 12, 10, 30, 10 and 19 days than lucerne, sainfoin, tall fescue, perennial ryegrass and cocksfoot, respectively), showed that early flowering was a good indicator of high dry matter yields (table III). Furthermore, the trait flowering data were negatively correlated with 
Table III. Correlation values among dry matter with trait plant height (PH), stem density (SD) and flowering data (FD) in the first harvest of the 1993 and 1994 years of evaluation in grass and legume species over the irrigation treatments.

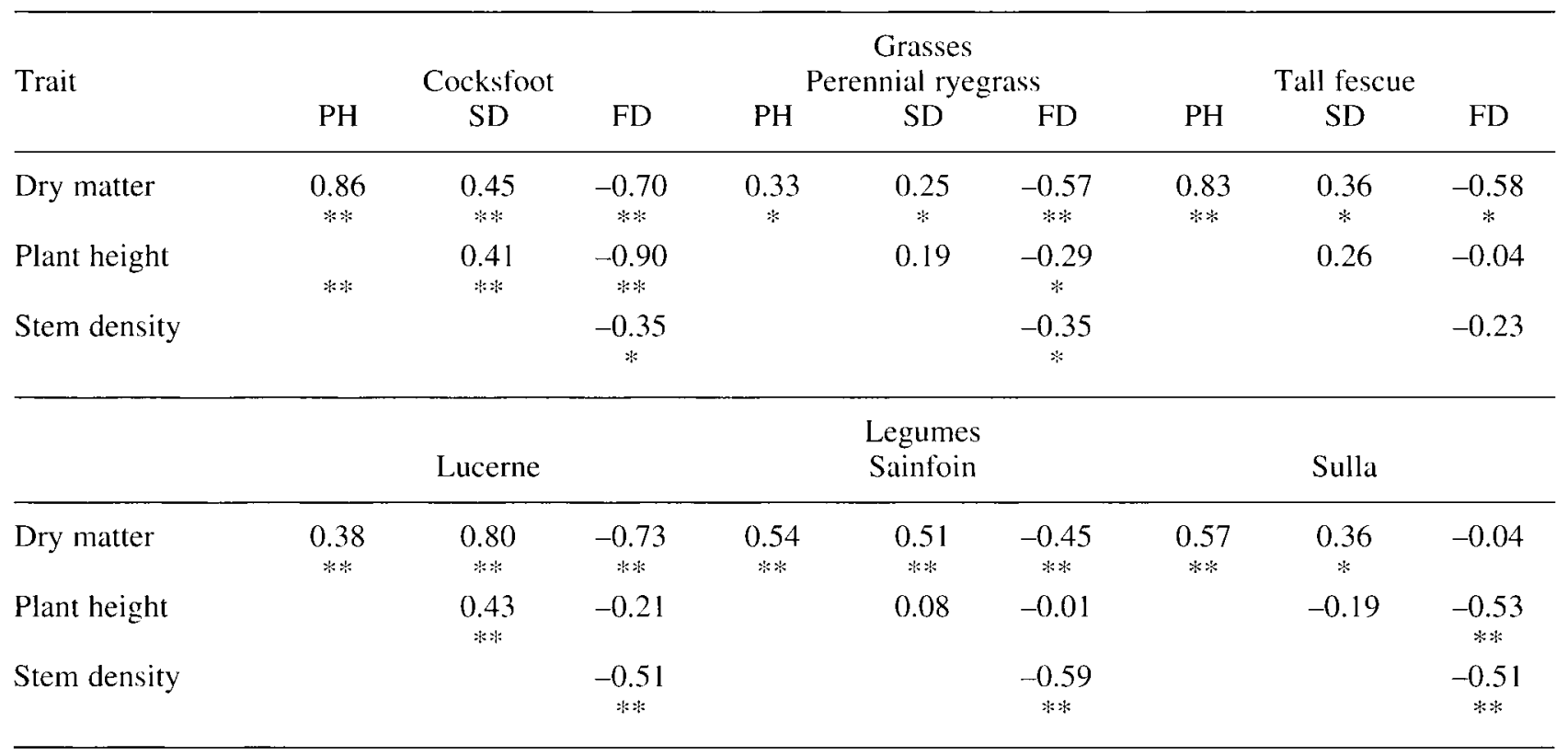

**** Significant at the $P \leq 0.05$ and $P \leq 0.01$ level of probability, respectively. Comparison made at 46 degrees of frecdom.

the stem density and plant height traits in the species cocksfoot, perennial ryegrass and sulla, and with stem density in all species of legumes and cocksfoot, and perennial ryegrass among the grasses. The relationship between dry matter and stem density was positively correlated in cocksfoot and in all species of legume.

\subsubsection{Seed yield and its yield components}

Relationships between seed yield and yield component traits in grass and legume species were differentially affected by rainfed and irrigation treatments. The consequence of more water being available during the seed filling period on seed yield showed a positive significant correlation of seed yield with stem density and seeds per stem, whose $r$ values are, respectively: $0.87 * *$ and $0.60 * *$ in cocksfoot, $0.95 * *$ and $0.62 * *$ in perennial ryegrass and $0.71^{* *}$ and $0.62^{* * *}$ in sainfoin under treatment $A$ and $0.85^{* *}$ and $0.82^{* *}$ in lucerne under treatment B. Seed yield was also positively correlated with stem density in tall fescue $\left(r=0.86^{* *}\right)$ and sulla ( $\mathrm{r}$ $=0.87 * *)$ under treatment $\mathrm{A}$; and in tall fescue $(\mathrm{r}=$ $\left.0.82^{* *}\right)$, perennial ryegrass $(\mathrm{r}=0.82 * *)$, lucerne $(\mathrm{r}$ $\left.=0.85^{* *}\right)$, sainfoin $\left(\mathrm{r}=0.53^{* *}\right)$ and sulla $(\mathrm{r}=$ $\left.0.48^{*}\right)$ under treatment $\mathrm{B}$. Correlations among components of seed yield and harvest index had $\mathrm{r}$ values of little interest from an agronomic point of view so they are not reported. The different relationships among seed yield components of grass and legume species under rainfed and irrigation treatments may reflect the biological pathways used by accessions of species to better exploit and adapt their cycle of growing to the environmental resource of locations $[1,5,7,15,20]$.

\subsubsection{Dry matter and seed yield components}

The correlation values and signs of dry matter and seed yield were affected by irrigation treatments and species of grasses or legumes (table $I V$ ). Significant positive correlations were observed in two species of grasses (tall fescue and perennial 
Table IV. Correlation values ( $r$ ) in the species of grasses and legumes between total dry matter produced in the year of evaluation and seed yield under rainfed and irrigation treatments.

\begin{tabular}{lcccccc}
\hline & \multicolumn{8}{c}{ Irrigation } \\
Species & \multicolumn{2}{c}{ Rainfed } & \multicolumn{2}{c}{ Treatment A } & \multicolumn{2}{c}{ Treatment B } \\
& $\mathrm{r}$ & $\mathrm{DF}$ & $\mathbf{r}$ & $\mathrm{DF}$ & $\mathrm{r}$ & $\mathrm{DF}$ \\
\hline & \multicolumn{6}{c}{ Grasses } \\
Cocksfoot & -0.20 & 22 & -0.15 & 14 & 0.21 & 14 \\
Tall fescue & $0.58^{*}$ & 22 & $0.68^{* *}$ & 14 & 0.12 & 14 \\
Perennial & & & & & & \\
ryegrass & 0.34 & 14 & $0.41^{*}$ & 14 & $-0.58^{*}$ & 14 \\
\hline & & \multicolumn{6}{c}{ Legumes } \\
Lucerne & -0.03 & 22 & -0.18 & 58 & $0.62 * *$ & 74 \\
Sainfoin & 0.31 & 6 & -0.28 & 14 & $0.45^{*}$ & 22 \\
Sulla & $0.41^{*}$ & 14 & -0.15 & 14 & $0.63^{* *}$ & 22 \\
\hline
\end{tabular}

$*$ * ** Significant at the $P \leq 0.05$ and $P \leq 0.01$ level of probability, respectively. $D F=$ Degree of freedom.

ryegrass) in treatment $A$ and in all species of legumes in treatment $B$. In contrast, the negative correlation of dry matter and seed yield observed in perennial ryegrass in treatment $B$ may be due to the higher stems per $\mathrm{m}^{2}$ (table $I$ ) than for cocksfoot and tall fescue which exploit the water resource more effectively, minimising the environmental impact on vegetative growth rather than seed production. There was little correlation between the other seed components and dry matter and so these data have not been presented in the table

\section{DISCUSSION}

In the 4 years of evaluation, irrigation treatments affected dry matter, seed yield and their yield components in all species of grass and legume. The lower dry matter observed in lucerne and sainfoin in the first harvest of the first year, was ascribed to the poor establishment of the crops. All accessions showed the highest dry matter and seed yield under irrigation treatments in the second year, as a consequence of higher stem density in the sward (table II). In agreement with Warringa and Kreuzer [20], their reduction in the following years of evaluation, in all irrigation treatments, was due to the reduction in stem density in the treatments A and B and a collapse of the plants under rainfed conditions. Moreover, the lower differences in dry matter observed in lucerne between harvests across the years of evaluation (data not shown) than those of other species, may be ascribed to the origin of the accessions which showed lower sensitivity to summer vegetative dormancy $[14,15]$. Thus, the cultivars of lucerne under favourable water conditions, as in the case of irrigation treatment $B$, were able to produce a high biomass during the summer season. Moreover, the species cocksfoot, tall fescue, perennial ryegrass, sainfoin and sulla showed summer dormancy and were unable to produce biomass in the summer although irrigated in late spring and summer. Thus, these perennial crops when grown in Mediterranean locations adapt the vegetative cycle to the environmental condition, producing most of their biomass in the spring, when the weather conditions are favourable to plant growth.

In agreement with Crespo [3], Tuttobene and Cavallaro [18] and Martiniello and Ciola [13], irrigation of forage species is a good agronomic practice that guarantees a stable seed yield in Mediterranean environments. The water applied under treatment B increased seed yield increasing stem density, number of seeds per stem and seed weight compared to treatment $\mathrm{A}$.

According to the results obtained on root development under controlled environments in perennial grass and legume species by Arcioni et al. [1], Rotili et al. [15], Janovszky [7] and Warringa and Kreuzer [20], it may be postulated that treatment B provides water to promote more seed production and for restoration of root-system reserves than treatment $A$, and finally increases sward persistence. Thus, the benefits resulting from treatment B were more apparent in the second and third year through increased fertility of inflorescences and seed weight. In contrast, water applied by irrigation treatment $A$, in sainfoin and sulla in the first year and perennial ryegrass and tall fescue in the second year, satisfied the requirement of the tillers during seed ripening without restoring the biochemical reserve in the plant. 
As suggested by Zannone et al. [22], Arcioni et al. [1], Janovszky [7], Warringa and Marinissen [21], Genter et al. [5] and Martiniello et al. [14], the different effects of irrigation treatments on the dry matter and seed yield components of the species, legume and grass cultivars may adopt different metabolic pathways to counteract the impact of the environment on the crops (table III). Early flowering in the accessions of all species was the trait which enabled the plant to produce higher dry matter and seed yield in the environment studied. Negative correlations between dry matter and flowering date across the species, demonstrated that cultivars which flowered earlier in the season were better adapted to escape the months with low rainfall in Mediterranean environments. According to Janovszky [7] and Warringa and Marinissen [21], the main differences under rainfed conditions among species of legumes and grasses may be ascribed to the relationship between flowering date and stem density traits. The different signs and values of significant correlations observed under rainfed and irrigation treatments between these two traits may be linked to the behaviour of legume and grass species in their reaction to the environmental condition imposed by the irrigation treatments. The positive and significant correlation observed in lucerne under treatment $B$ was due to the cultivars being summer active which resulted in a good seed and dry matter production under irrigation treatment B compared to the other legume and grass species.

The higher number of correlations among seed yield and yield components in grasses under rainfed and irrigation treatment $A$ than those of legumes may denote different physiological strategies for supporting seed yield components among accessions of grass and legume species. Significant correlations among yield components with a positive sign observed in the species of grasses and legumes under irrigation treatment $A$ and rainfed condition may be due to the fact that under limited water resources one trait of seed yield prevails over the others utilising the photosynthates to supply seed production rather than in restoring the reserves of the plant $[1,6,7,12,19,20]$. Thus, the consequence was a decrease in the plant reserve for regrowth and a reduction in the period of agronomic utilisation of meadow. In contrast, the increased water availability achieved by irrigation treatment $B$ increases the environmental resources available more than does treatment A, allowing the possibility for yield component traits to counteract among themselves in a way to better exploit the resources available and to maintain active photosynthesis and physiological processes which support seed yield and plant regrowth for a longer period.

The correlations between total dry matter production in the year of evaluation and seed yield among species of grass and legume were scant and with a different sign among irrigation treatments, which may indicate that the traits are independent and differently influenced by weather and irrigated conditions (table $I V$ ). According to Khalak and Gowda [8], Janovszky [7], Warringa and Kreuzer [20] and Genter et al. [5], enviromental resources (e.g. water) interfere with flowering date and harvest index (data not presented) in grass and legume species influencing photosynthesis and consequently the biological mechanisms which support persistence, dry matter and seed yield. Thus, in agreement with the results obtained by Liang et al. [11], Gumaniuc [6] and Lorenzetti [12], it is possible to assume that the genetic basis of dry matter, seed yield and their components are specific and their expression is influenced by environmental factors.

\section{CONCLUSIONS}

Dry matter, seed yield and yield components of the species react differently to the agronomic factors considered in the experiments. The research underlines the importance of early flowering in cultivars, the advantages of irrigation in increasing forage and seed production and in minimising the effect of drought stress on the crops. Treatment B increases the utilisation period of the cultivars for dry matter and seed yield exploitation rather than treatment A and rainfed. Dry matter yield of the first harvest did not substantially differ among the irrigation treatments. Seed yield components that were more influenced under treatment A were stem 
density and seeds per stem in grasses and in legumes, and stem density, seeds per stem and seed weight in grasses, and stem density and seeds per stem in legumes under treatment B. Irrigation treatment $\mathrm{B}$ was the agronomic factor able to increase both seed yield in the cultivars and the number of cropping years. The relationship between dry matter and seed yield across the species and irrigation treatments was weak and influenced by water availability during the growing season. Moreover, with limited water resources of rainfed and treatment $\mathrm{A}$, photosynthates were used to develop seed components rather than restore reserves supporting plant growth.

Acknowledgements: The work was funded by special project 'Foraggicoltura prativa' of the Ministery of Agricultural Politics. The author expresses appreciation to technicians V. Franco and E. D'Andrea and Dr G. D'Agnano for their assistance in the field experiment; Dr V. Di Bari, for providing the meteorological data and Professor F. Veronesi and R. Wilkins for suggestions and critical reading of the manuscript.

\section{REFERENCES}

[1] Arcioni S., Falcinelli M., Mariotti D., Ecological adaptation in Lolium perenne L. Physiological relationships among persistence, carbohydrate reserves and water availability, Can. J. Plant Sci. 65 (1985) 615-624.

[2] Caballero R., An experts' survey on the role of forage legumes in arable cropping systems of the Mediterranean area, J. Sustainable Agric. 3 (3/4) (1993) 133-154.

[3] Crespo D.C., Problems and potentialities of pasture and forage production in Portugal, Melhoramento 26 (1980) 151-176.

[4] Doorenbos J., Pruitt W.O., Irrigation and drainage, paper no. 24, Food and Agriculture Organization of the United Nations, Rome, Italy, 1977.

[5] Genter T., Deleens E., Fleury A., Influence of photosynthetic restriction due to defoliation at flowering on seed abortion in lucerne (Medicago sativa L.), J. Exp. Bot. 48 (1997) 1815-1823.
[6] Gumaniuc L., Studies on genetic control of seed yield in lucerne, Probleme de Genetica Teorica si Aplicata 3 (1971) 153-159.

[7] Janovszky J., Effects of production factors on quality and quantity of seed yield of tall fescue (Festuca arundinacea Schreb.), Hortic. Sci. 28 (1996) 77-81.

[8] Khalak A., Gowda M.K.M., Seed yield of lucerne (Medicago sativa L.) varieties at different dates of sowing and levels of fertility, Mysore J. Agric. Sci. 23 (1989) 14-17.

[9] Kowithayakorn L., Hill M.J., A study of seed production of lucerne (Medicago sativa L.) under different plant spacing and cutting treatments in the sowing year, Seed Sci. Technol. 10 (1982) 3-12.

[10] Lelievre F., Mansat P., La production de semences fouragères et les recherches nécessaires pour l'améliorer dans les pays Méditerranéens de la CEE, in: Caredda S., Roggero P.P. (Eds.), Sementi per le colture foraggere meditarranee, Arti Grafiche Editoriale Chiarella, Sassari, Italy, 1992, pp. 83-108.

[11] Liang G.H.L., Rield W.A., Agronomic traits influencing forage and seed yield in alfalfa, Crop Sci. 4 (1964) 394-396.

[12] Lorenzetti F., Relationship between dry matter and seed yield in leguminous forage plants, in: Proceeding of the Eucarpia Fodder Crop Section Meeting, Breeding High Yielding Forage Varieties Combined with High Seed Yield, Merelbeke-Gent, Belgium, 1981, pp. 57-74.

[13] Martiniello P., Ciola A., The effect of agronomic factors on seed and forage production in perennial legumes sainfoin (Onobrychis viciifolia Scop.) and French honeysuckle (Hedysarum coronarium L.), Grass Forage Sci. 49 (1994) 121-129.

[14] Martiniello P., Paoletti R., Berardo N., Effect of phenological stages on dry matter and quality components in lucerne, Eur. J. Agron. 6 (1997) 79-87.

[15] Rotili P., Zannone L., Proietti S., Lucerne meadow structure. analysis of aerial part and roots. II Sugar content, in: Proceedings of the 11 th Meeting of Fodder Crops Section of Eucarpia, Svalöv, Sweeden, 1985, pp. $16-17$

[16] Schaber B.D., Charnetski W.A., Entz T., Early and late-season insecticide applications in seed alfalfa: impact on pest species and seed yield, J. Entomol. Sci. 25 (1990) 548-558.

[17] Steel R.G., Torrie J.H., Principles and Procedures of Statistics. A Biometrical Approach, 2nd ed., McGraw-Hill, New York, 1980. 
[18] Tuttobene R., Cavallaro V., Influenza dell'epoca di raccolta sulla produzione del seme in Dactylis glomerata L. e Festuca arundinacea Schreb., Rivista di Agronomia 22 (1988) 185-188.

[19] Veronesi F., Falcinelli M., Seed yield selection in Medicago sativa $\mathrm{L}$. and correlated responses affecting dry matter yield, Plant breeding 99 (1987) 77-79.

[20] Warringa J.W., Kreuzer A.D.H., The effect of new tiller growth on carbohydrates, nitrogen and seed yield per ear in Lolium perenne L., Ann. Bot. 78 (1996) 749-757.

[21] Warringa J.W., Marinissen M.J., The effect of light intensity after anthesis on dry matter distribution and seed yield of Lolium perenne L., Grass Forage Sci. 51 (1996) 103-110.

[22] Zannone L., Assemat L., Rotili P., Jacquard P., An experimental study of intraspecific competition within several forage crops, Agronomie 3 (1983) 451-459. 